\title{
STRATEGI PENGENDALIAN DISORIENTASI SISWA DalaM BelajaR DI SEKOlaH
}

\author{
QMuhammad SMisdar
}

\author{
Program Pascasarjana \\ Universitas Islam Negeri Raden Fatah Palembang \\ E-mail:misdar@radenfatah.ac.id
}

\begin{abstract}
Student learning situations in schools do not always benefit psychologically for certain students and teachers, because there are attitudes and behaviors of students that show contradiction with should occur. Ideally, the student should seriously study but is sometimes shown by aberrant behavior. Student learning orientation should focus on achieving success, get maximum achievement in a school, but sometimes fact justeri on the contrary, studying student no more just doing duty for the sake of pleasing parent and reach social status finished school. What is described above, the emergence is not without cause, the attitude of disorientation of students' learning in school is basically sourced from internal students themselves rather than from external factors. Students' disorientation in learning does not just appear, but arises from a cause, among them is the negative cycle of academic development experienced by students, low perceptions of learning, and effort in learning is very low. The adverse effects of these three factors will also affect students' attitudes toward learning, such as the use of ego in learning is greater than the logic, avoidance of challenges, such as dislike of difficulties, because it does not like to something hard and become a heavy burden for the brain, So can not measure the success and failure in learning. The consequences of it all have an effect on their behavior, such as tend to be difficult to control to learn by the teacher, ignorance of the teacher and the lesson, likes to belittle the lesson learned, the less attention to the lesson and sometimes show the destructive behavior when facing the excessive challenge in learning, So the challenge he likes to be physically fit is not an intellectual challenge. In order to provide solutions to the attitudes and behaviors of students as described above, there needs to be a breakthrough that can be done, at least can be done through two kinds of strategies, namely motivation strategy and emotional strategy. Both are solutions that are internal rather than external.
\end{abstract}

Keywords: Disorientation of learning, students, school and strategy, control

\begin{abstract}
Abstrak
Situasi belajar siswa di sekolah tidak selalu memberi keuntungan secara psikologis bagi siswa tertentu dan guru, karena ada sikap dan perilaku siswa yang menunjukkan pertentangan dengan seharusnya terjadi. Idealnya siswa itu belajar dengan serius tetapi kadang-kadang sebaliknya ditunjukkan dengan perilaku yang menyimpang. Orientasi belajar siswa seharusnya fokus menggapai keberhasilan, mendapatkan prestasi yang maksimal di suatu sekolah, tetapi kadang-kadang fakta justeri sebaliknya, belajar siswa tidak lebih hanya sekedar melaksanakan tugas demi menyenangkan orang tua dan menggapai status sosial tamat sekolah. Apa yang dijelaskan di atas, munculnya bukan tanpa sebab, sikap disorientasi belajar siswa di sekolah pada dasarnya bersumber dari internal siswa itu sendiri bukan dari faktor eksternal. Disorientasi siswa dalam belajar tidak muncul begitu saja, tetapi muncul dari suatu sebab, diantaranya adalah siklus negatif perkembangan akademik yang dialami siswa, persepsi rendah terhadap belajar, dan usaha dalam belajar sangat rendah. Dampak buruk dari ketiga faktor tersebut akan berpengaruh pula pada sikap siswa terhadap cara belajarnya, seperti penggunaan ego dalam belajar lebih besar dari pada logikanya, sikapnya menghindari tantangan, seperti tidak suka pada kesulitan, karena tidak suka kepada sesuatu yang susah dan menjadi beban berat bagi otak, sehingga tidak dapat mengukur keberhasil dan kegagalannya dalam belajar. Akibat dari semuanya itu berpengaruh pula pada perilakunya, seperti cenderung sulit dikendalikan untuk belajar oleh gurunya, sikap cuek pada guru dan pelajaran, suka meremehkan pelajaran yang dipelajari, kurang perhatian terhadap pelajaran dan kadang-kadang menunjukkan berperilaku destruktif bilamana mengahadapi tantangan yang berlebihan dalam belajar, sehingga tantangan yang disukainya tatangan fisik bukan tantangan intelektual. Dalam rangka memberi solusi terhadap sikap dan perilaku
\end{abstract}




\section{Haril Penelitian}

siswa sebagaimana dijelaskan di atas, perlu ada terobosan yang dapat dilakukan, minimal dapat dilakukan melalui dua macam strategi, yaitu strategi motivasi dan strategi emosi. Keduanya merupakan solusi yang bersifat internal bukan eksternal.

Kata kunci: disorientasi belajar, siswa, sekolah dan strategi, pengendalian

Persoalan siswa dan belajarnya di sekolah, dihadapkan pada dua permasalahan pokok, yaitu bersifat internal dan eksternal. Permasalahan kenakalan, sikap siswa terhadap pelajaran, pencapaian hasil belajar yang kurang maksimal, sikap acuh pada pelajaran, orientasi pada belajarnya tidak jelas. Semua permasalahan internal itu berdampak buruk pada hasil belajar siswa. Disorientasi belajar siswa adalah salah satu kajian psikologi yang masih minim dilakukan dan sangat minim diketahui oleh para guru. Umumnya guru berasumsi bahwa disorientasi belajar itu berakar pada faktor eksternal, seperti pergaulan di luar sekolah, dan keadaan pendidikan di rumah tangga termasuk bagian dari penyebab pembelajaran siswa di sekolah tidak terarah.

Apa yang dijelaskan di atas sesungguhnya tidak sepenuhnya benar, karena disorientasi belajar siswa sebagian besar berakar pada internal siswa itu sendiri, apalagi bagi anak-anak usia remaja seperti siswa MTs dan SMP, tetapi siklus negatif kegagalan akademik yang pernah ditempuh sebelumnya, persepsinya terhadap keberhasilan dan kegagalan dalam belajar tidak mendalam bahkan cenderung negatif, usaha yang digunakan untuk mengendalikan situasi tersebut sangat tipis, serta kontrol diri terhadap situasi yang dialami oleh siswa tersebut sangat rendah. Dari beberapa faktor tersebut pasti mememberi dampak buruk terhadap kemunculan siklus kepribadian siswa dalam belajar, seperti; egois, menghindari tantangan dalam belajar, tidak dapat mengenal dengan mendalam akan kemampuan intelektualnya.

Kegagalan dalam beberapa faktor itulah yang meyebabkan siswa sulit dikendalikan dalam belajar oleh guruya, meremehkan pelajaran, acuh dan tidak perduli dengan hasil yang dicapai dan cenderung destruktif dalam berperilaku, bahkan dampak lebih buruk orientasi belajar kadangkadang bertolak belakang dengan tujuan belajar sesungguhnya. Karena itu, sifat internal yang berakar dari dalam diri siswa lebih kentara dari pada gejala yang lainnya. Maka salah satu cara mengatasi keadaan tersebut adalah dengan melakukan pembenahan secara internal pula, oleh sebab itu strategi motivasi dan strategi emosi dapat menjadi salah satu solusi yang dapat dugunakan dalam mengendalikan disorientasi belajar siswa tersebut.

\section{Fenomena Disorientasi Belajar Siswa di Sekolah}

Pada dasarnya siswa di dalam suatu sekolah hanya dapat diklasifikasikan menjadi siswa normal dan kurang normal dalam belajarnya. Jarang sekali ditemukan yang abnormal, kecuali terjadi pada sekolah-sekolah khusus untuk orang-orang yag abnormal. Disorientasi belajar bagi siswa, bukanlah sesuatu yang baru dalam dunia pendidikan, terutama di lingkungan sekolah, karena disorientasi belajar siswa ada kaitannya dengan permasalahan yang dialami oleh siswa baik bersifat internal maupun eksternal. Permasalahan personalitas belajar siswa adalah yang bersifat internal sangat dominan dalam memunculkan disorientasi tersebut. Situasi dan kondisi pembelajaran yang dilakukan guru yang bersifat eksternal adalah sisi lain, turut memberi dampak memperparah kondisi tersebut.

Secara spesifik disoreintasi belajar siswa adalah gejala siklus negatif yang dialami oleh setiap siswa dalam belajar dengan beragam fenomenanya yang bersifat internal. Namun secara umum fenomena tersebut dapat dikelompokkan menjadi dua permasalahan dasar yang dihadapi oleh setiap siswa. Pertama adanya keraguan internal secara berkelanjutan akan kemampuan belajar masingmasing siswa dan kedua kemampuan akademik yang telah mereka raih adalah sesuatu yang tidak dapat mereka kontrol secara permanen. Dari kedua perrmasalahan tersebut berakibat pada beberapa sikap negatif dalam diri siswa, seperti sikap frustasi dan mudah menyerah dalam mengerjakan tugas, kurangnya usaha untuk bekerja, dan keuletan menjadi sesuatu yang sangat sulit mereka lakukan, sehinga semuanya itu memberi kontribusi pada kegalalan lebih mendalam, sehingga memperkuat keyakinan akan negativisme dalam diri untuk belajar. 


\section{Haril Penelitian}

Disorientasi belajar siswa tidak berdiri sendiri, dan tidak muncul secara tiba-tiba, tetapi kemunculan disorientasi ada kaitannya dengan perkembangan psikologi belajar yang dialami siswa. Gejala negativisme sebagaimana dijelaskan di atas, selanjutnya kadang-kadang dapat memunculkan gejala yang lain, pelampiasannya secara internal maupun secara eksternal. Seperti kenakalan siswa di sekolah tidak dapat berdiri sendiri, dan boleh dikatakan kenakalan itu dilatarbelakangi oleh gajala negatif yang bersifat internal, sementara kenakalan mereka di luar belajar yang bersifat eksternal tentu berdampak pada negativisme terhadap belajar mereka. Namun yang sangat perlu diketahui adalah semuanya itu bermuara pada perkembangan psikologis dan situasi belajar seorang siswa yang sedang mereka alami.

\section{Faktor-Faktor Disorientasi Belajar Siswa dalam Belajar}

Banyak defenisi tentang belajar, namun secara ringkas belajar secara ilmiah adalah aktivitas perubahan seseorang dari tidak tahu menjadi tahu, dari tidak mengenal menjadi mengenal dari bodoh menjadi pintar. Dari situlah selanjutnya belajar dapat dimaknai sebagai aktivitas menuju kehidupan yang lebih baik secara sistematis (Rahyubi, 2012:3). Bilamana belajar berorientasi pada perubahan kualitas kehidupan, maka belajar yang sesungguhnya menunjukkan tiga perubahan pokok dalam diri seseorang, yaitu: pertama, membawa perubahan dalam arti behavioral changes, kedua, perubahan pada pokoknya adalah didapatkannya kecakapan baru baik yang bersifat aktual maupun potensial; ketiga perubahan itu terjadi karena usaha dengan sengaja (Suryabrata, 2004: 232).

Dari penjelasan tersebut dapat disimpulkan bahwa inti belajar adalah adanya perubahan baik yang bersifat hihavioral maupun potensial, demi mendapatkan kecakapaan baru demi kehidupan. Namun semua itu belum akan berarti apa-apa kalau tidak didukung dengan usaha sengaja. Mengacu pada penjelasan tersebut tersebut pada dasanya semua orang ingin berubahan, dan perubahan itu akan terjadi dengan sendirinya ataukah tidak, tergantung pada kehidupan seseorang. Perubahan secara fisik sudah pasti akan terjadi tetapi perubahan dalam arti behavioral, perubahan dalam kecakapan, dan perubahan dalam hal potensial, seutuhnya tidak akan terjadi dengan sempurna kalau tidak melalui suatu proses belajar.

Itulah defenisi belajar secara normal, karena belajar secara normal seperti disebutkan di atas, namun demikian belajar juga sering tidak normal sehingga dapat menunjukkan perbedaan hasil belajar dengan seharusnya diterima siswa. Ketidaknormalan belajar dapat disebabkan oleh beberapa faktor yang berasal dari luar diri siswa itu sendiri, seperti faktor nonsial dan faktor sosial. faktor non sosial sperti pengaruh cuaca, waktu belajar pada pagi hari atau sore hari, alat yang digunakan dalam belajar apa saja dll. Sedangkan faktor sosial adalah faktor yang ada di sekeliling belajar itu, seperti keramaiaan siswa, kehadiran atau ketidakhadiran dalam belajar. Adapun faktor yang berasal dari dalam diri siswa itu sendiri terdiri dari dua faktor, yatu faktor fisiolgis, seperti struktur tubuh atau jasmani dan fungsi-fungsinya serta faktor psikologis, seperti keingintahuan, kreativitas untuk menjukkan hasil belajar kepada seseorang (Suryaberata, 2004: 231-237).

Dari beberapa indikator yang disebutkan di atas, bagi siswa-siswa yang memiliki disorientasi dalam belajarnya, biasanya gejala-gejala kekurangan dan kelemahan pada diri siswa tersebut sangat tampak, seperti; tidak pernah fokus pada pelajaran, di sekolah sering membolos, kurang perhatian terhadap pelajaran yang menjadi tanggungjawabnya, ketika belajar lebih banyak diam dan tidur-tiduran serta tidak pernah terarah pikirannya kepada materi pelajaran. Aktivitas belajarnya tidak lebih sekedar menyelesaikan tugas sekolah agar dapat disebut tamat dari sekolah tersebut, lalu mendapatkan ijazah. Bilamana dikaji secara mendalam siswa-siswa yang berperilaku demikian tidak semata-mata disebabkan oleh faktor eksternal yang dialami oleh siswa, tetapi faktor internal dari dalam diri siswa itu sendiri lebih dominan dari pada faktor eksternal. Faktor-faktor eksternal bukanlah awal pemicu perilaku tersebut, tetapi perilakunya diluar tersebut adalah akibat dari kondisi belajarnya di sekolah sudah bermasalah, siswa-siswa itu itulah yang banyak mengalami disorientasi dalam belajarnya.

Bila dikaji secara mendalam, dari sudut internal kondisi disorientasi siswa dalam belajar sebagaimana disebutkan di atas, dapat disebabkan oleh beberapa faktor seperti penjelasan di bawah ini: 


\section{Haril Penelitian}

Pertama, disebabkan oleh siklus negatif dalam kegagalan akademik yang pernah dialami oleh siswa. Licht \& Kitesner, (1966 dalam Schunk mengatakan bahwa siswa yang memiliki masalah dalam belajar semuanya berawal dari adanya siklus negatif, berinteraksi dengan kegagalan akademik (Schunk, 2012: 522). Hal ini tidak hanya sematamata oleh karena faktor nilai yang rendah yang dihasilkannya, tetapi ada sesuatu yang melekat dalam diri siswa, bahwa siswa tersebut tidak dapat mengikuti pelajaran yang diajarkan guru. Seperti ketidakmampuan dalam mengikuti suatu pelajaran, menjadi salah satu pemicu kelemahannya dalam belajar sehingga pelampiasannya berubah dari seharusnya dia belajar, menjadi membenci pelajaran. Ketidaktertarikan siswa pada pelajaran beragam alasannya, bisa saja berakar dari siswa itulah maupun berakar dari gurunya.

Dalam satu faktor biasanya berakar pada diri siswa. Apa yang disampaikan Imam Gozali dalam rangka pembinaan siswa, menyebutkan bahwa janganlah mengajarkan ilmu di atas pengetahuan siswa (Al-Gozali, tt:........, ).Artinya pengetahuan yang belum diketahui siswa, menjadi salah satu pemicu siswa tidak mau terlibat dalam pembelajaran. Tidak selalu peralihan siswa dari satu materi pelajaran ke materi yang lain disebabkan oleh guru yang kurang menarik dalam belajarnya, tetapi bisa saja hal itu disebabkan oleh siswa tidak tertarik pada materi pelajaran yang disampaikan guru itu belum seharusnya mereka ketahui, atau memang pelajaran yang diberikan guru itu bukan menjadi minat siwa untuk mempelajarinya.

Kedua, persepsi rendah terhadap kelemahan dan kegagalan. Setiap siswa pasti pernah megalami kegalalan dalam mata pelajaran. Tetapi tidak banyak siswa yang mampu mengatasi persoalan kegagalan dalam pelajarannya. Siswasiwa yang dapat mengatasi seluruh mata pelajarannya adalah siswa yang sangat khusus, tetapi secara umum siswa pernah mengalami masalah dalam belajar, seperti kegalalan dalam mata pelajaran tertentu, sulit mempelajari pelajaran tertentu, tidak semua pelajaran yang diberikan sekolah menjadi minat siswa mempelajarinya, sehingga akhirnya mereka gagal dalam pelajaran. Sebaliknya pengendalian terhadap keberhasilan menjadi sesuatu yang sering bermasalah, seperti sikap eporia, atau sebaliknya menghindari pelajaran tertentu akibatnya keberhasilan dapat menjadi pemicu kegagalan, apalagi bagi siswa yang menghindari pelajaran tertentu.

Dampak dari situasi yang demikian tersebut, setiap siswa menginterpretasikan setiap keberhasilan dan kegagalan mereka selalu dikaitkan dengan faktor ekternal. Bahkan gurupun sering memberi apresiasi negatif yang sama dan semua permasalahn disorientasi belajar siswa bersifat eksternal. Sebaliknya keberhasilan siswa dalam belajar sering dihubungkan dengan soal yang mudah, adanya keberuntungan yang diraih, dan kadang-kadang mendapat bantuan dari guru secara tidak langsung dalam ujian. Tetapi bagi mereka yang gagal dalam belajar, mereka sering menghubungkannya dengan kerendahan kemampuan, diasumsikan secara internal yang bersifat personal, sehingga sosialnya pun tidak stabil, dampaknya pun akan melekat pada efikasi diri dan motivasi untuk berprestasi. (Nolen, Hoeksema, Girgus \& Sleigmena, 1996), dalam scnhunk, 2012: 522). Semuanya itu berdampak pada kekurang seriusan pada pelajaran, akibatnya sudah dapat dipastikan secara akademik, sikapnya terhadap pada pelajaran sangat rentan sehingga prestasinyapun tidak akan meningkat.

Ketiga, usaha yang rendah dalam belajar. Penelitian yang dilakukan oleh para peneliti seperti, Beorsama \& Cahpman (1981) Butkowsky \& Willows (1980), Chapman (1988), Palmer, Drummond, Tollison \& Zinkgraff (1982) seperti dijelasakan dalam (Schunk, 2012: 522) menemukan bahwa siswa yang kurang normal secara akademik selalu berhadapan dengan masalah dalam belajarnya. Mereka secara umum memiliki perkiraan yang sangat rendah akan kesuksesan. Mereka menilai diri mereka memiliki kemampuan yang rendah dalam persoalan akademik, asumsi itulah yang menjadi pangkal kegagalan. Dari penjelasan tersebut menunjukkan bahwa sikap yang rendah tertanam dalam diri, seperti merasa tidak mampu dan cepat putus asa menjadi salah satu pemicu kegagalan dalam belajar. Orientasi belajar yang seharusnya dilakukan dengan sungguhsungguh, beralih menjadi malas, pasrah, dan tidak ada daya untuk belajar.

Siswa-siswa yang bersikap demikian itu tidak punya semangat dalam belajarnya, datang ke 


\section{Haril Penelitian}

sekolah bukan untuk belajar, tetapi sebaliknya hanya sekedar menghabiskan waktu agar mendapatkan ijazah. Belajar tidak lebih hanya sekedar melepas beban dari orang tua agar tetap bersekolah. Mereka itu sebagaimana dikemukakan oleh Andrews \& Debus (1978; Dweck (1975; Pear, Bryn \&Donahue (1980) dalam (Schunk, 2012;522) jarang sekali menghubungkan kegagalan yang mereka raih dengan usaha mereka yang rendah. Artinya orientasi belajar siswa yang rendah secara akademik lebih dominan berakar pada masalah kepribadian siswa itu sendiri bukan pada orang lain.

Keempat, kontrol diri yang rendah. Penelitian yang dilakukan oleh Jhonson (1981; Licht dan Kitsner (1986) dalam Schunk 2012: 522) menunjukkan bahwa secara umum siswa yang memiliki disorientasi dalam belajar tidak menunjukkan sikap satria, tidak suka pada tantangan, mereka cepat menyerah ketika menghadapi kesulitan, dan memiliki persepsi kontrol internal yang rendah terhadap keberhasilan dan kegagaalan dalam belajar. Akibatnya mereka sering menyamaratakan kepercayaan negatif ke dalam siatuasi yang mereka alami sebelumnya dengan apa yang akan mereka alami selanjutnya. Persepsi kegagalan bagi siswa yang tipe kontrol diri yang rendah sangat tinggi, sehingga pengalaman yang pernah dialami sebelumnya bukan dijadikan sebagai alat untuk memotivasi diri, tetapi sebaliknya persepi dirinya terhadap hal tersebut dipermanenkan dalam dirinya, bahwa seperti itu pula yang akan dialami selanjutnya. Tidak seperti siswa kontrol dirinya kuat. Siswa dengan tipe kontrol diri kuat, pengalaman sebelumnya adalah alat untuk memotivasi diri agar pelajaran sulit harus dapat dikuasai, tetapi bagi mereka yang memiliki kontrol diri rendah pengalaman masa lalu akan terulang kembali, dan terus berulang lagi. Sehingga kondisi itulah yang menyebabkan mereka tidak pernah bangkit dari keterpurukan dalam belajar.

Beberapa tokoh seperti Dweck menggabungkan ketidakberdayaan itu dengan model berprestasi yang rendah (Dweck, 1986), di mana efikasi diri untuk meraih sesuatu yang lebih baik dari sebelumnya tidak muncul dari dalam diri siswa tersebut. Oleh sebab itu ada beberapa ciri kontrol diri yang rendah yang terdapat dalam diri seorang siswa, secara umum menyebabkan belajar menjadi negatif. Salah satu aspek negatif itu berakar pada diri siswa itu sendiri, seperti:

\section{Keterlibatan Ego Lebih Besar dalam Belajar Dari Pada Intelektual.}

Ada kecenderungan permanen bahwa siswa yang sulit berprestasi bahkan cenderung kurang berprestasi dan tidak pernah meraih prestasi, memunculkan oreintasi belajarnya tidak jelas. Mereka umumnya berada di antara keterlibatan ego dalam dirinya sangat besar dari pada keinginan belajarnya. Dwek (1986) dalam Schunk megatakan bahwa siswa-siswa yang menunjukkan gejala yang dimaksud, umumnya mereka berpersepri bahwa tujuan sekolah adalah menyelesaikan tugas dan menghindari negatif atas kompetensi mereka miliki. Sehingga kecederungan pikiran mereka mengarah pada negativisme yang mencirikan bahwa intelegensi merupakan kuantitas yang stabil (Schunk, 2012: 522). Mereka umumnya tidak dapat mengklasifikasikan bahwa intelegensi bukan kuantitas yang konstan dan baku, tetapi mereka cirikan bahwa kemampuan intelegensi atau kemampuan otak senantiasa stabil. Padahal sesungguhnya kemampuan otak dan intelegensi senantiasa berubah dan berkembang seiring dengan kuantitas penggunaannya.

Keadaan inilah yang membuat kemampuan belajar baik dalam hal motivasi untuk belajar, motivasi membaca, motivasi ingin mendapatkan sesuatu dari belajarnya, bahkan keinginan untuk berprestasinya sangat rendah. Secara personal saja siswa-siswa yang dimaksud jarang menunjukkan kepribadian yang antusias terhadap pelajaran, kecenderngannya cuek, acuh tak acuh pada pelajaran bahkan kepada gurunyapun dia acuh. Tidak ambil pusing dengan tugas-tugas belajarnya. Terhadap tugas seperti pekerjaan rumah (PR), bagi mereka belajar seakan-akan hanya melepas beban saja dan lebih banyak meniru dari kawan-kawan yang sudah selesai mengerjakannya. Harapan untuk memiliki nilai yang lebih tinggi tidak ada, tidak ambil pusing dengan kawan mereka yang memiliki nilai yang bagus.

\section{Menghindari Tantangan Secara Intelektual}

Di samping apa yang disebutkan di atas, secara personal siswa yang memiliki kontrol diri yang rendah memiliki sikap selalu menghindari diri 


\section{Haril Penelitian}

dari tantangan, terutama tantangan intelektual. Penelitian Diener \& Dwek (1978) dalam Schunk menunjukkan sikap keuletan yang sangat rendah dalam menghadapi kesulitan, siswa yang memiliki kontrol diri rendah selalu memegang persepsi yang rendah mengenai kemampuan dan merasakan cemas ketika melaksanakan tugas (Schunk, 2012: 522.). Tidak banyak harapan untuk menghadapai sesuatu yang sulit. Belajar pada dasarnya adalah menghadapi persoalan hidup dalam kaitannya dengan pengetahuan. Bilamana tantangan yang menjadi ciri utama dalam menuntut suatu pengetahuan, siswa yang memiliki kontrol diri yang rendah tidak menunjukkan jiwa juangnya utuh, bahkan memiliki jiwa juangnya saja ia tidak punya. Bertolak belakang dengan siswa yang berprestasi yang suka dengan tantangan, karena mereka berpegang pada cara berpikir maju dan berkembang menuju pencapaian yang maksimal dalam melaksanakan tugas. Sehingga intelegensi bisa berkembang dan tujuan mereka sekolah adalah untuk belajar menjadi lebih kompeten, dan memiliki kapabilitas yang tinggi terhadap belajar, dan mereka sering mencari tantangan, ulet dalam menghadapi tugas yang sulit.

\section{Tidak dapat Membedakan Kapasitas Intelektual Diri Sendiri}

Salah satau ciri siswa yang kontrol dirinya yang rendah adalah memiliki kekurangan pada kemampuan kognitif (Schunk, 2012:522), tetapi tidak selalu kondisi itu dapat menyebabkan mereka gagal dalam belajar dan tidak semua siswa masuk dalam kategori siklus tersebut, hanya saja siswa yang sering mengalami kegagalan dalam belajar lebih rentan terhadap permasalahan khusus dalam belajar. Hasil penelitian Licht dan Kistner (1986) sebagaimana disebutkan dalam Schunk mengatakan bahwa salah satu sisi yang dapat memperparah kondisi tersebut adalah defisit membaca (Schunk, 2012: 553). Kemampuan intelektual rendah ataukah tinggi, bagi siswa yang memiliki kontrol diri yang rendah tidak ada bedanya dalam pandangan mereka. Kondisi tersebut diperparah dengan defisit membaca.

Kemampuan membaca menjadi salah satu kendala bagi siswa yang kontrol dirinya rendah, bahkan membaca seakan-akan menjadi beban. Lebih parah lagi orientasi terhadap buku sangat minim. Padahal bagi siswa yang cerdas dan kontrol dirinya baik, membaca adalah menjadi kesukaannya. Kekurangan membaca menjadi siklus kehidupan negatif bagi pembelajaran siapa saja, termasuk bagi seorang siswa. Membaca adalah kunci untuk menambah kapasitas diri dan dapat mengurangi siklus negatif terhadap diri sendiri. Seperti hasil penelitian Schunk menunjukkan bahwa depisit membaca dapat memunculkan keyakinan nagatif bahkan di area yang melibatkan membaca sedikit atau sama sekali tidak membutuhkan bacaan (Schunk,2012: 553).

Dari penjelasan di atas dapat disimpulkan bahwa ada hubungan antara kontrol diri rendah dalam belajar dengan difisit membaca. Membaca menjadi kunci utama untuk menemukan teori, peningkatan pengetahuan dan memperbesar kapasitas kognitif. Kognitif bertambah luas tentu dapat mengimbangai kontrol diri yang rendah. Semakin tinggi konrol diri seseorang, sudah dapat dipastikan kapasitas intelektualnya tinggi, intetelektual yang tinggi pasti dapat diduga bahwa seseorang itu memiliki kontrol diri yang baik, salah satu faktor dominan mendongkrak situasi itu adalah intensitas membaca yang tinggi. Permasalahan membaca tidak semua siswa memiliki apasitas yang sama, tetapi kekurangan membaca adalah salah satu pemicu kurangnya kapasitas kognitif. Sedangkan dalam belajar membaca adalah menjadi ciri utama untuk meningatkan kapasistas intelektual, yang menjadi salah satu alat kontrol diri.

\section{Dampak Disorientasi dalam Pembelajaran Terhadap Perilaku}

Suatu proses pembelajaran banyak hal yang harus menjadi perhatian para pendidik, baik terhadap siswa yang memiliki disoriented dalam belajarnya. Di antara ciri siswa yang disoriented seperi telah dijelaskan di atas. Salah satu yang sangat menonjol adalah kontrol dirinya yang rendah terhadap pembelajaran. Beragam gejala dapat dimunculkan dari dampak tersebut, dengan berbagai indikatornya, sperti: gerakan egonya lebih besar, menghindari tantangan, dan tidak dapat membedakan kemampuan intelektuanya secara khusus. Namun secara khusus siswa yang disoriented dalam belajar dapat menunjukkan gejala seperti penjelasan di bawah ini: 


\section{Hasil Penelition}

\section{Sulit Dikendalikan Guru}

Guru sering mengalami kegalauan dalam mengajar, tidak puas dengan cara dan hasil belajar siswanya, bahkan kadang-kadang ditunjukkan dengan sikap marah, lebih dari itu siswa yang mengalami gangguan sosial dalam belajar, bahkan disorientasi dalam belajar diasumsikannya sebagai anak nakal atau dengan berbagai nisbah lainnya yang diberikan kepada mereka. Secara khusus siswa yang menunjukkan gejala orientsi belajarnya menyimpang di dalam kelas sangat sulit dikendalikan guru bahkan kadang-kadang ditunjukkannya dengan sikap melawan. Sikap guru yang galau terhadap siswa yang disorientasi belajarnya, salah satu faktornya bukan disebabkan oleh pembelajarannya yang diterapkannya tidak menarik, tetapi disebabkan oleh ketidatahuaan guru tentang sebab-sebab siswa yang memiliki sikap menyimpang dalam belajar tersebut.

Bagi seorang guru prinsip dasar yang harus diketahuinya adalah bahwa siswa sekolah itu adalah kelompok anak usia remaja memang sedang masuk dalam masa transisi (Sarwono, 2005:3). Apabila asumsi guru terhadap siswa sering tertanam dengan negatif, sebagaimana disebutkan di atas, maka dapat dipastikan apa akibatnya. Semuanya dapat memberi dampak yang baik maupun buruk, baik bagi siswa dalam belajar maupun bagi guru itu sendiri dalam mengajar. Pengaruh yang paling tampak terletak strategi pembelajaran yang dilakukan guru dalam membelajarkan siswa sering kurang tepat, apalagi guru kurang didukung pengetahuan secara teoretis. Apalagi strategi yang digunaannya dalam menghadapi siswa yang orientasi belajarnya tidak jelas. Akibatnya akan muncul konprontasi psikologis antara siswa yang belajar dan guru yang mengajar.

\section{Meremehkan Pelajaran}

Sikap suka meremehkan pelajaraan dan bahkan meremehkan guru tidak muncul dengan begitu saja dalam suatu proses pembelajaran. Tetapi gejala itu adalah suatu siklus yang menunjukkan adanya akumulasi psikologis siswa dalam pembelajaran. Kontrol diri siswa yang sangat rendah dapat memberi dampak terhadap siklus negatif tersebut. Sering dilupakan oleh guru dan bahkan semua pendidik, pembelajaran apapun yang dilakukan guru harus sesuai dengan perkembangan anak", termasuk pembelajaran yang dilaksanakan guru di dalam kelas, karena pengajaran yang dilakukan guru umumnya hanya berupa pemberian informasi kepada siswa (Schunk, 2012: 823).

Cara tersebut kelihatannya positif, tetapi apabila hanya menekankan pada aspek tersebut dan mengabaikan aspek yang lain, sikap itulah yang disebutkan dengan siklus negatif. Pembelajaran hanya dengan memberikan informasi kepada siswa adalah salah suatu teori dari mengajar, dibalik teori itu ada teori lain lagi yang dibutuhkan, yaitu teori yang dipergunakan untuk memproses informasi yang disebut dengan teori pengolahan informasi, atau teori-teori yang lainnya. Sementara kemampuan mengolah informasi sangat terkait dengan perkembangan siswa, teori-teori tersebut sering terlupakan oleh guru ketika mengajar atau ketika membelajarkan siswa.

Dale H. Schunk mengatakan dalam bukunya bahwa ada tiga tahap pembelajaran yang sesuai dengan perkembangan terutama dalam kaitannya dengan pengolahan informasi pada suatu pembelajaran tertentu (Schunk, 2012: 624). pertama, siswa menyusun pengetahuan berdasarkan pengalaman mereka sebelumnya dan kedua menampilkan skema, karena pengetahuan tidak pernah dikirim secara otomatis, ketiga penyusunan pengetahuan dan integrasi dengan struktur mental terkini merupakan cara pembelajaran dilakukan. Hal ini membutuhkan pengajaran yang dirancang untuk membantu penyusunan pengetahuan tersebut. Dalam teori (Pieget) disebut pula dengan teori eksplorasi aktif, dan pernyataan sesuai dengan metode pengajaran.

\section{Acuh dan Tidak Perduli dengan Hasil yang Dicapai}

Kaitannya dengan penjelasan tersebut di atas, kemampuan siswa dalam menyusun pengetahuan tentunya tidak saja bergantung kepada siswa itu sendiri, tetapi guru yang berada di luar siswa menjadi faktor lain menyebabkan siswa mampu mengolah informasi yang didapatinya. Strategi guru mengajar dapat dianggap menjadi salah satu langkah yang punya kaitan langsung dengan kemampuan siswa tersebut. Namun lingkungan sosial merupakan faktor tidak kalah penting dalam pembelajaran. Vygotsky dalam Dale H.Schunk mengatakan bahwa ketika seorang anak 


\section{Hasil Penelitian}

berinteraksi dengan orang lain, anak menerima ide dan opini yang bertentangan dengan ide dan opnini mereka. Hal ini memunculkan proses keseimbangan (Pieget dan Meece 2002). Pertentangan kognitif yang terjadi dipandang sebagai pendorong di balik pembelajaran, di samping sebagai sarana untuk menolak. Dari teori tersebut ada kemungkinan bahwa anak-anak yang sulit diatur oleh guru dalam belajar di sekolah, bahkan mungkin yang memiliki disorientasi dalam belajar ada kaitannya dengan pandangan tersebut. Kontradiksi secara kognitif dapat berdampak pada kontradiksi afektif. Kemampuan belajar siswa yang diindikasikan dengan kontrol diri rendah, hal semacam itu menjadi sesuatu yang paling menentukan dalam keberhasilannya. Artinya usaha untuk mengharmonisasikan antara guru dengan siswa dalam proses pembelajaran menjadi vital artinya bagi siswa.

\section{Kecenderungan Berperilaku Destruktif}

Sikap destruktif bukan sesuatu yang sangat krusial dalam pembelajaran, tetapi mengabaikannya akan menjadi masalah besar bilamana tidak ditemukan solusinya. Sikap destruktif muncul akibat adanya pertentangan secara negatif. Sebagai contoh, pertentangan tercipta berawal ketika materi pelajaran yang dipelajari berada di luar pemahaman terkini siswa, hal inilah yang menyebabkan munculnya zona of proximal development, yaitu suatu masa di mana pendedalian diri siswa dapat dilakukan melalui tiga zona, mandiri, guru atau orang lain dan teman sejawat. Yang di dalamnya terjadi melalui perbedaan kognitif, refeksi dan penyusunan kembali konsep (Meece 2002) pertentangan hanya sedikit terjadi ketika materi terlalu berkembang jauh dari pemahaman terkini siswa.

Pertentangan yang sama akan terjadi bilamana pembelajaran berada jauh di bawah tingkat pemahaman siswa. Apalagi bilamana pembelajaran itu belum sesuai dengan perkembangan diri siswa, pembelajaran disampaikan guru mengalami loncatan terlalu jauh dari pemikiran siswa, atau terlalu rendah atau bahkan menggunakan strategi yang kurang jelas, maka sangat berdampak pada pembelajaran di sekolah. Perkembangan diri siswa menjadi salah satu karakterstik kepribadian siswa, dari karateristik itu akan memunculkan karakteristik dalam belajar. Peampiasan siswa terhadap hal-hal yang negatif, seperti melawan guru, berkelahi atau bahkan merusak fasilitas belajar dapat diasusmsikan sebagai akumulasi dari sikap disorientasi dalam menghadapi belajar. Hal itu akan diperparah dengan karakteristik individual dengan konrol diri yang rendah.

\section{Strategi Pengendalian Disorientasi Belajar Siswa di Sekolah}

Variabel lingkungan belajar siswa menjadi salah satu faktor yang dapat memberi dorongan secara negatif terhadap kondisi siswa yang bermasalah dalam belajarnya, sehingga orientasi belajarnya tidak fokus. Sebagai bagian dari solusinya guru harus mampu memberi tugas yang dapat dikerjakan siswa agar dapat menyoroti kemajuan dan mencapai tujuan belajar yang sebenarnya, meskipun apa yang dilakukan guru hanya bersifat umpan balik semata. Solusi yang tepat menurut Stipek dan Kowalski dalam Schunk (2012,:533), guru harus dapat menemukan strategi yang tepat, seperti memberi tugas, seperti diketahui bahwa tugas itu memiliki peran dalam usaha menaikkan kinerja akademik siswa yang bermasalah dalam belajarnya (1989). Ada dua strategi yang dapat dilakukan dalam mengendalian disorientasi belajar siswa di sekolah. Adapun dua strategi tersebut adalah:

\section{Strategi Melalui Peningkatan Motivasi}

Ada beberapa langkah yang dapat dilakukan oleh seorang guru dalam pemberian strategi dalam kaitannya dengan memberi motivasi siswa. Di antaranya adalah:

Pertama, membuat kesatuan kinerja yang bisa dijalankan secara mental oleh siswa, seperti menilai diri sendiri, Kinerja dimaksud dapat meningkatkan rasa tanggung jawab siswa terhadap diri sendiri. Seorang guru harus dapat membuat suatu kegiatan yang dapat menjadikan siswa itu mengerti akan dirinya. Seperti memberi tugas khusus pada siswa tersebut secara mendiri, tetapi dilakukan secara terbimbing oleh guru dalam suasana kerja, tetapi dapat pula dilakukan secara terpisah dari komunitas siswa yang lain. Guru mengkondisikannya secara personal dalam situasi 
belajar khusus. Kondisi tersebut memungkinkan siswa dapat bekerja nyaman dan aman. Suasana aman dan nyaman itulah yang menjadi tujuan dari kegiatan tersebut. Bilamana suasana nyaman dirasakan siswa sudah ditemukan, maka siswa yang memiliki orientasi berbeda dengan tujuan belajar, dapat diarahkan guru untuk belajar dengan serius. Pegendalian dengan penilaian diri sendiri, secara akademik dapat dilakukan guru melalui kegiatan secara rutin, kegiatan tersebut tidak dapat dilakukan hanya sekali, tetapi harus dilakukan secara kuntinyu dengan kegiatan yang bervariasi.

Kedua, meningkatkan tujuan dengan memprioritaskan dan membayangkan nilainya, nilai dalam arti bilaman siswa mengerjakan sesuatu tugas yang diberikan guru yang tertanam di pikiran siswa itu adalah nilai yang baik. Memberi harapan nilai yang baik bagi siswa, diharapkan siswa dapat mengerjakan tugas dengan baik pula, sehingga dapat menjadi salah satu solusi dilakukan bagi siswa-siswa yang memiliki disorientasi dalam belajarnya. Fokus utamanya pembelajarannya dilakukan guru bukan pada nilainya, tetapi proses mengkonentrasikan siswa pada pelajaran, kondisi dibuat sedemikian rupa, sehingga fokus siswa harus terarah seratus persen kepada tugas atau pelajaran yang telah disiapkan guru. Bagi siswa yang pada awalnya tidak fokus dalam belajar, dapat terarahkan pada pelajaran hanya karena ada harapan nilai yang akan diraih dari gurunya.

Strategi tersebut meskipun tidak permanen, tetapi dapat dijadikan sebagai tindakan pemula dalam pengendalian orientasi siswa dalam belajar. Konsistensi selanjutnya menjadi masalah, karena suasana batin siwa tidak selalu stabil. Dari situlah ada tindakan yang berkelanjutan dari seorang guru. Seperti; tidak menjadikannya sebagai objek atau contoh dari kegagalan. Tetapi sebaliknya kegagalan dan disoreintasinya dijaga melalui pendekatan dengan dilakukan secara personal oleh guru. Kegagalan yang dialami dijadikan pemicu keberhasilannya melalui peningkatan aktivitas yang dikendalikan langsung oleh guru.

Ketiga, memvisualisasikan pelaksanaan kerja yang telah berhasil. tindakan demikian dilakukan dengan memberikan contoh orang-orang yang berhasil dalam belajarnya, melalui suatu media vissual tertentu, atau melalui media tertulis yang diberikan kepada siswa yang memiliki sikap disorientasi dalam belajarnya, sehingga sesuatu keberhasilan dapat dilihatnya, meskipun dapat pula dilakukan dalam komunitas siswa secara umum, apa yang dilakukan ada keniscayaannya dapat memberi nilai positif terhadap perkembangan kognitif siswa yang lemah dalam orientasi belajarnya.Yang menjadi tujuan akhir dari strategi tersebut adalah adanya perubahan kognitif terhadap kegagalan, bahwa kegalalan tidak selamanya menjadi orang gagal, tetapi kegagalan itu adalah kesusksesan yang tertunda. terlalu sering berpretensi negatif terhadap kegagalan akan mengalami kegagalan yang sebenarnya. Dengan cara memberi contoh komparatif antara kegagalan dan harapan kesuksesan, niscaya dapat mengugah kognitif dan sikap siswa terhadap kegagalan, bahwa sesungguhnya kegagalan yang pernah diraih tidak ada apa-apanya. Tapi lihatlah orang-orang yang sukses, mereka itu semua berasal dari orang yang pernah mengalami kegagalan.

Keempat, membuka jalan untuk membuat pekerjaan lebih menarik atau menantang. Yang perlu diketahui dari siswa-siswa yang disorientasi dalam belajarnya adalah tidak suka pada tantang secara intelektual, Tahap pertama yang perlu diberi solusi kepada mereka adalah memberi kesempatan dalam bentuk uji coba, uji coba dapat dilakukan secara berulang-ulang, agar mereka terbiasa dengan kondisi yang berbeda dengan kehendaknya. Siswasiswa yang tidak suka pada tantangan secara intelektual, sangat lemah dalam menghadapi problem akademik. Tujuan utama dari pekerjaan tersebut memberi kesempatan kepada siswa agar selalu berada dalam situasi untuk memecah masalah dan mencari solusinya terhadap problem belajarnya sendiri. Siswa tidak diarahkan selalu pasrah dan menunggu kebaikan hati para guru. Belajar perlu bekerja keras, belajar memerlukan tenaga, belajar memerlukan usaha yang yang lebih penting memerlukan kekuatan intelektual, belajar memerlukan ketentangan hati agar apa yang dihadapai dapat diselesaikan dengan baik.

Tugas guru menjadi bertambah ekstra dari biasanya, karena yang dihadahapi bukan siwasiswa yang biasanya, tetapi siswa-siswa yang membutuhkan pengendalian motivasi dan emosi. Siswa-siswa yang lemah dalam belajar biasanya motivasinya sangat rendah untuk menjadi orang berhasil, dan lesu bila dihadapkan pada tugas-tugas 


\section{Haril Penelitian}

akademik yang menantang. Untuk itulah siswasiswa yang demikian itu senantiasa diarahkan untuk dapat megendalikan dirinya sendiri melalui bantuan motivasi dan emosi dari seorang guru, guna menuju aktualisasi diri yang sesungguhnya secara permanen. Pengendalian diri tersebut dapat diangap sebagai sisi lain dari cara pandangan tentang menguatkan motivasi siswa, teknik ini pula sesuai dengan pandangan Goble yang disebutnya sebagai aktualisasi diri (Goble, 1971: 77), di dalam teori tersebut seseorang harus berkembang menjadi salah satu unsur dalam penanganan keterbasan belajar siswa, siswa tidak saja sebagai objek yang termotivasikan tatapi yang lebih penting siswa adalah subjek belajar.

Dari situlah arti penting dari strategi tersebut sebagai bagian dari pengendalian diri siswa dalam memajukan pembeajarannta, terutama bagi siswa yang selalu menghadapi problem dalam belajar, khususnya bagi siswa-siswa yang orientasi belajarnya sering tidak terarah. Orientasi belajarnya sering menyimpang oleh hal-hal yang sepele. Strategi tersebut harus senantiasa dilakukan secara gradatif dan berulang-ulang agar tercipta suatu kondisi yang meyenangkan bagi siswa dalam belajar.

Kelima, menganalisis kegagalan untuk diarahkan ke pada percobaan kedua dan terus kepada kelanjutannya. Yang perlu diketahui oleh setiap siswa adalah satu prinsip dasar yang harus ditanamkan dalam diri siswa itu adalah bahwa bekerja keras untuk belajar itu tidak akan merusak (Slameto,2010:79). Tugas gurulah untuk menyampaikan hal tersebut. Konsentrasi penuh, membutuhkan waktu yang lama, memakan waktu berjam-jam dalam belajar, meskipun terasa letih hal itu tidak akan sampai merusak. Boleh jadi kegagalan siswa dalam belajar belum menggunakan seluruh potensinya untuk belajar, akibatnya prestasi menjadi menurun, ketika prestasi terus turun maka prustasipun menjadi muncul, sehingga menyebakan orientasi belajar menjadi tidak terarah. disitulah pentingnya menanamkan kepada siswa sikap positif dalam belajar. Bahwa belajar maksimal itu penting dalam meraih keberhasilan. Menggunakan waktu dengan maksimal sangat penting. Belajar empat hingga delapan jam perhari sudah cukup untuk memberi hasil yang maksimal terhadap belajar (Slameto, 2010: 79).

\section{Strategi Melalui Peningkatan Emosi}

Memberi terapi dengan menghitung angka hingga sepuluh. Memperhatikan point tersebut seakan-akan tidak punya arti apa-apa hanya dengan memberi terapi dengan menghitung angka hingga sepuluh misalnya. Makna dibalik terapi itu adalah memberi ruang agar emosinya terkendali. Orientasi belajar yang tidak terarah bahkan kadang-kadang menyimpang tidak saja oleh kemampuan belajar seseorang siswa itu lemah, tetapi gejala psikologis lebih tinggi dari pada gejala gejala kemampuan intelektuanya. Teknik tersebut minimal dapat memberi kesempatan kepada seorang siswa agar sadar akan dirinya. Stephen Copey dalam Agus Wibowo dan Hamrin menyebutkan bahwa kesadaran akan diri menjadi salah satu anugrah Tuhan yang diberikan kepada manusia (Wibowo dan Hamrin, 2012: 144).

Teknik meningkatkan emosi sebagaimana disebutkan di atas adalah salah satu cara untuk mendapatkan feed back tentang ketenangan. Ketenangan adalah pangkal dari kesadaran. Kesadaran akan diri sendiri, adalah pangkal untuk melangkah lebih jauh menuju kesuksesan. Keberhasilan belajar salah satunya disebabkan oleh ketenangan. Bukankah inti dari pada kontrol diri seperti disebutkan di atas adalah keasadaran akan diri. Kontrol diri yang rendah menunjukkan kesadaran akan dirinya rendah pula.

Menghasilkan hiburan yang bermanfaat (seperti bernyanyi sendiri). Ada kalanya kejenuhan siswa dalam belajar berakibat fatal, seperti menunjukkan aktivitas yang bertolak belakang dengan keadaan yang sebenarnya, bahkan kadangkadang sampai pada kegiatan yang destruktif sebagaimana disebutkan diatas. Bagi guru yang mengenal dengan tingkah laku siswanya, apalagi bagi guru yang mendapat tugas sebagai wali kelas, salah satu cara yang solutif adalah dengan memberikannya "ruang" untuk bersenang-senang di dalam kelas. Mengkondiskan situasi tersebut di antaranya melalui bernyanyi secara personal.

Tekanan intelektual dalam belajar berakibat positif tetapi dapat pula berakibat negatif. Secara positif siswa akan terbiasa menghadapi, memecah masalah, mengendalikan emosi serta membiasakan dewasa akan diri sendiri. Tetapi dampak negatifnya juga bisa terjadi, terutama bagi 


\section{Haril Penelitian}

siswa-siswa yang kontrol dirinya rendah, emosinya rendah dan egonya tinggi. Siswa-siswa semacam ini kadang-kadang tidak melihat tekanan intelektual itu sebagai sarana untuk menuju kepintaran, tetapi dianggapnya sebagai kesusahan. Keadaan seperti itu selalu diberi pengertian kepada siswa, bahwa belajar keras, susah payah, tekanan otak untuk mengulangi pelajaran tidak akan merusak fisik.

Mempertimbangkan perasaan negatif terkait pengalaman dan cara untuk lebih memastikannya. Oleh sebab itu terhadap faktor ini siswa harus diberi kekuatan dalam dirinya agar semangatnya bangkit dalam belajar. Untuk menghilangkan perasaan negatif itu perlu ada motivasi dari luar diri siswa agar, sehingga emosinya bangkit. Perasaan negatif beralih menjadi positif, salah satu unsur itu adalah mendorong diri siswa untuk bangkit, bahwa sesungguhnya di dalam diri siswa itu ada kekuatan-kekuatan yang perlu mendapat perhatian dari siswa itu sendiri. Di antara kekuatan itu adalah satu; kekuatan impian atau lebih jelasnya disebut pula dengan tujuan hidup yang jelas; kedua kekuatan fokus, kekuatan fokus menjadi daya tarik tersendiri untuk melihat sesuatu termasuk untuk menatap masa depan; ketiga kekuatan disiplin; kekuatan perjuangan (Wiboowo dan Hamrin, 2012:145.

Dari ketiga macam kekuatan tersebut bagi siswa yang disorientasi dalam belajarnya sangatlah lemah biasanya, akan tetapi melalui motivasi guru, emosi siswa akan terpancing sesaat. Walaupun hanya sebentar peralihan emosi siswa sudah dapat dirubah dari lemah menjadi kuat, dari unfokus menjadi fokus, dari meremehkan mulai bangkit perhatiannya. Tugas guru selanjutnya terus melakukan hal yang sama agar situasi siswa yang mengalami disorientasi dalam belajar, defisit membaca, kontrol diri rendah dapat dibanagkitkan melalui kegiatan guru yang dilakukannya secara reguler dan gradatif.

\section{Kesimpulan}

Dari uraian di atas dapat disimpulkan menjadi beberapa point penting: Pertama, disorientasi belajar siswa di sekolah sebagian besar bersumber dari dalam diri siswa itu sendiri bukan dari luar diri siswa. Faktor luar adalah sesuatu yang terpisah dengan situasi belajar siswa di sekolah, dan boleh jadi perilaku di luar adalah pelampiasan atas ketidakpuasaanya di sekolah.

Kedua, disorientasi belajar bagi siswa tidak muncul begitu saja, tetapi muncul dari suatu proses sebab akibat, di antara sebab itu adalah siklus negatif perkembangan akademik yang dialami siswa, persepsi rendah terhadap belajar, usaha belajar yang rendah.

Ketiga, dampak buruk dari ketiga unsur tersebut di atas akan berdampak pada sikap kepribadian siswa dalam belajar, seperti keterlibatan egonya dalam belajar lebih besar dari pada logikanya, sikapnya menghindari tantangan, karena tidak suka kepada sesuatu yang susah dan berat bagi otak, tidak dapat mengukur keberhasil dan kegagalannya dalam belajar, belajarnya sepertinya tidak ada gairah, belajar tidak lebih sebagai tuntutun sosial belaka.

Keempat, dampak dari itu semua sikap tersebut di atas, akan berakibat pada perilaku siswa di sekolah, perilaku mereka cenderung sulit dikendalikan untuk belajar, seperti acuh pada guru, suka meremehkan pelajaran yang dipelajari, kurang perhatian terhadap pelajaran dan cenderung berperilaku destruktif bilamana mengahadapi tantangan yang berlebihan.

Kelima dalam rangka memberi pelayanan yang solutif terhadap sikap dan perilaku siswa sebagaimana dijelaskan di atas, dapat dilakukan melalui dua macam strategi, yaitu strategi motivasi dan strategi emosi.

\section{Daftar Pustaka}

Desmita. Psikologi Perkembangan Peserta Didik Panduan bagi Orang Tua dan Guru dalam Memahami Psikologi Anak Usia SD, SMP dan SMA. Bandung: Rosdakarya. 2011.

Hurlock, Elizabeth B. Perkembangan Anak jilid II terjemahan oleh Meitasari Tjandrasa. Jakarta: Erlangga. 1978.

Sarwono, Sarlito Wirawan. Psikologi Remaja. Jakarta: Raja Grafindo Persada. 2005.

Scunk, Dale H. Learning Theories, An Educational Persefective: Teori-teori Pembelajaran persfektif Pendidikan. Tejemahan oleh Eva Hamidah dan Rahmat Fajar, Pustaka Pelajar. Yogyakata. 2012.

Suryabrata, Sumadi. Psikologi Pendidikan. Jakarta: Raja Grafindo Persada. 2004. 


\section{Hagil Penelition}

Slameto. Belajar dan faktor-faktor yang Mempengaruhi. Jakarta: Renika Cipta. 2010.

Rahyubi, Heri. Toeri-teori Belajar dan Aplikasi Pembelajaran Motorik Deskripsi dan Tinjauan Kritis. Majalengka: Referens. 2012.
Goble, Frank, G. Mazhab Ketiga Psikologi Humanistik Abraham Maslow. Kanisuis. 1971.

Wibowo, Agus dan Hamrin. Menjadi Guru Berkarakter. Yogyakarta: Pustaka Pelajar. 2012. 